\title{
Comparison of Perception of the Prolonged /s/ in Korean by Average Adult Listeners and Speech-Language Pathologists
}

\author{
Jin Park' , Je-Pyo Jun², Inkie Chung ${ }^{3}$ \\ 'Division of Human Rehabilitation Services, Catholic Kwandong University, Gangneung, Korea \\ ${ }^{2}$ Department of Speech-Language Therapy and Research Institute of Speech Science, Chonbuk National University, Jeonju, Korea \\ ${ }^{3}$ Department of English, Sogang University, Seoul, Korea
}

\section{‘’ 연장음에 대한 일반인과 언어재활사 간의 지각 비교}

박 진 $^{1} \cdot$ 전제 $\mathbb{\#}^{2} \cdot$ 정인기 ${ }^{3}$

가톨릭관동대학교 휴먼재활서비스학부 ${ }^{1}$, 전북대학교대학원 언어치료학과 및 음성과학연구소 ${ }^{2}$, 서강대학교 영미어문전공 ${ }^{3}$

\begin{abstract}
Purpose: This study examines 1) whether two groups of Korean listeners (i.e., average adult listeners and speech-language pathologists) show any difference(s) in the minimal duration of the prolonged Korean fricative /s/ perceived as 'abnormal' and 2) whether the two groups perceive the prolonged sound 'categorically' or 'continuously.' Methods: Fifty participants ( 25 average adult listeners and 25 speech-language pathologists) have been asked to identify whether each version of the plain voiceless fricative $/ \mathrm{s} /$ in the word san 'mountain' produced by a normally fluent Korean speaker and manipulated to create a range of prolonged sounds (i.e., from $0 \mathrm{~ms}$ to $380 \mathrm{~ms}$ by 20-ms increments) is normal (0) or abnormal (1), and to rate each version of the fricative based on a rating of normal to abnormal (or stuttered) (1 to 100). Results: Results show that the minimal threshold for the prolonged sound perceived as 'abnormal' is $375 \mathrm{~ms}$ for average adult listeners and $355 \mathrm{~ms}$ for speech-language pathologists. In addition, both groups perceive the range of sounds more continuously than categorically. Also, a significant group difference exists in that speech-language pathologists rate disfluent sounds more strictly (or higher) than average adult listeners. Conclusion: Speech-language pathologists are more sensitive than average adult listeners. The implications of these results are further discussed.
\end{abstract}

Key Words: Stuttering, Sound prolongation, Categorical perception, Continuous perception, Korean fricative /s/.

Received: May 29, 2018 / Revised: July 1, 2018 / Accepted: July 9, 2018

Correspondence: Inkie Chung, Department of English, Sogang University, 35 Baekbeom-ro, Mapo-gu, Seoul 04107, Korea Tel: +82-2-705-8844 / Fax: +82-2-715-0705 / E-mail: inkiechung@sogang.ac.kr

\section{INTRODUCTION}

대표적인 유창성장애의 하나인 말더듬은 분절음, 음절, 어휘 등이 비정상적으로 반복되거나 연장 또는 막힘으로 인해 발화 의 산출이나 흐름이 원활하지 않은 현상을 일컫는다(Perkins, 1983; Van Riper, 1982; Wingate, 1988). 반복, 연장, 막힘 등은 말더듬의 주요한 언어적 핵심행동인데, 이러한 말소리 붕괴현상 의 핵심행동 중에서 연장은 단일한 날숨에서 조음기관이 움직 이지 않는 고정된 상태에서 특정 분절음이 비정상적으로 지속 되는 현상이다(Lee, 2005; Van Riper, 1982). 예를 들어, '산'이 라는 어휘의 음절을 발음할 때 초성 ''의 조음이 지속되면서
이 분절음을 뒤따르는 모음 '아로 전이가 곧이어 이루어지지 않 는 상태를 말한다. 일반적으로 하나의 분절음을 0.5 초 이상 발 음하면 말더듬 연장으로 규정하기도 하지만 극단적인 경우에는 2 3분까지 연장하는 경우도 있다(Lee, 2005). 그런데, 현재까지 말더듬으로서 인식되는 연장의 최소길이에 대한 구체적인 수량 적 기준은 제시되지 않았다(Kawai et al., 2007; Kawai \& Healey, 2012).

현재까지 연장음 인식의 최소길이에 대한 연구는 주로 영어 권 화자를 대상으로 수행되었는데 특정 분절음에 따라 비교적 다양한 결과를 보이고 있다(Jones et al., 2005; Lingwall \& Bergstrand, 1979; Susca et al., 2001). 예를 들어, Lingwall \& 
Bergstrand(1979)는 유성마찰음(/z/)이 $294 \mathrm{~ms}$ 이상 지속될 때, Susca et al.(2001)은 모음(/i/), 성문마찰음 $(/ \mathrm{h} /)$, 유음(//r/) 모두 $300 \mathrm{~ms}$ 이상일 때, Jones et al.(2005)은 유성마찰음(/z/) 은 $235 \mathrm{~ms}$ 이상, 모음(/a/)은 $279 \mathrm{~ms}$ 이상 지속될 때 비정상적 인 연장으로 인식되었다고 보고하고 있다. 이들 연구는 기본적 으로 비정상적인 연장으로 인식되는 최소길이의 수량적 기준이 있으며 이를 경계로 하여 정상/비정상 또는 유창함/비유창함 (말더듬)으로 구분된다는 '범주적 지각'(Liberman et al., 1958; Lisker \& Abramson, 1967; Pisoni et al., 1994)의 양상을 보인 다는 가정을 바탕으로 하고 있다.

한편, 몇몇 연구자(Adams \& Runyan, 1981; Susca \& Healey, 2002)는 유창성이 단속적이 아닌 연속적으로 지각되는 개념이 라고 주장하고 있다. 즉, 유창성이 단순히 유창함과 비유창함 (말더듬)으로 구분되는 이분적 개념이 아닌, 유창함, 약간 덜 유창함(또는 약간 덜 비유창함), (매우) 비유창함(또는 말더듬) 에 이르는 연속선상에서 점진적으로 지각되는 것이라는 것이 다. 그렇기에 유창성에 관련된 수량적 기준 또한 이러한 연속선 상에서 파악되어야 한다는 것이다. 이와 관련해 Kawai et al. (2007)은 실험을 통하여 연장이 범주적이 아닌 연속적으로 지 각됨을 보인다고 주장하였다. 구체적으로, 특정 문장(즉, “These take the shape of a long round arch.”) 내의 특정음(즉, 'shape' 에서 / $/ \mathrm{J} /$ )의 길이를 원래의 길이인 $120 \mathrm{~ms}$ 부터 $500 \mathrm{~ms}$ 까지 20 $\mathrm{ms}$ 씩 총 19번 연장하여 총 20개의 문장자극을 생성하여 이를 실험대상자들에게 들려주고 (비)유창함의 정도에 따라 1 부터 100 까지의 척도로 평가[100에 가까울수록 매우 비유창함(또는 말더듬)]하게 하였다. 실험결과 해당 분절음의 길이가 증가할수 록 비유창함으로 지각되는 정도(점수)가 증가하였으며 이러한 지각 양상은 완만한 S자 곡선 모형(sigmoidal curve)의 연속선 형태로 나타났다. 결국 Kawai와 동료들은 이를 실험대상자들 이 분절음 연장을 범주적이 아닌 연속적으로 지각하는 것이라 고 주장하였다. 또한 이들은 이러한 연장 지각에서 남녀 차이 가 있는지도 알아보았는데, 남녀 모두 연장을 비슷한 양상으로 연속적으로 지각하는 것으로 나타났다. 지각 정도(점수)에 대 해서는 상대적으로 더 유창하게 들리는 연장자극(즉, $/ \mathrm{J} /$ 의 마 찰구간의 길이가 $120 \mathrm{~ms}$ 부터 $200 \mathrm{~ms}$ 까지)에서 남자 대상자들 이 더 높은 점수로 평가한 반면, 상대적으로 더 비유창하게 들 리는 연장자극(즉, $/ \mathrm{g} /$ 의 마찰구간의 길이가 $420 \mathrm{~ms}$ 부터 500 $\mathrm{ms}$ 까지)에서는 여자 대상자들이 더 높은 점수로 평가하였다.

위에서 언급한 것처럼 이전 연구(Jones et al., 2005; Kawai et al., 2007; Lingwall \& Bergstrand, 1979; Susca et al., 2001) 는 주로 영어권 화자를 중심으로 행해져 왔다. 이에 비해 말더 듬의 핵심행동에 대한 지각 양상에 대한 국내 연구는 매우 제 한적이며, 특히 말더듬으로서 연장에 대한 지각 연구는 현재까
지 거의 수행되지 않았다. Gregory et al.(2003)은 연장이 특정 분절음의 차이, 연장과 관련된 질적 변화[예, 긴장(tension)이나 음조 변화의 유무 또는 청자 간의 차이에 따라 다르게 인식될 수 있다고 주장한다. 앞에서 기술한 대로 이전 연구에서도 특 정 분절음이나 청자의 차이에 따라 비교적 다양한 결과가 나타 났다. 하지만 청자의 차이와 관련해 몇몇 연구(Jones et al., 2005; Kawai et al., 2007; Lingwall \& Bergstrand, 1979)에서 는 비교적 말더듬(인)에 대한 경험이 없는 일반인들을 대상으로 한 반면, 다른 연구(Susca et al., 2001)에서는 유창성장애 평가 및 치료에 있어 전문가라고 할 수 있는 언어치료사나 말더듬(인) 에 지식이나 경험이 비교적 많을 수 있는 언어치료학 전공 학생 들이 실험대상이었다. 말더듬(인)에 대한 상당한 경험 또는 전문 성의 유무에 따라서 말더듬 연장 지각에 대한 차이가 발생할 가 능성이 있음에도 불구하고, 아직까지 서로 다른 두 대상, 즉 말 더듬(인)에 대한 경험이 비교적 없는 일반인과 상대적으로 관련 전문성이나 경험이 많은 대상(예, 언어치료사나 언어치료 전공 자 또는 말더듬인 가족 구성원)에 대한 지각 차이에 대한 비교 연구는 없다. 상대적으로 부족한 임상 경험 시간으로 인해 언어 치료사들이 다른 의사소통장애(예, 아동언어장애, 조음음운장 애)의 경우보다 말더듬 치료를 더 까다로워하는 경향성을 고려 할 때(Shin \& Choi, 2012; Sommers \& Caruso, 1995) 말더듬 (인)에 대한 경험 또는 전문성(임상 경험) 유무의 차이는 단순히 일반인과 언어재활사의 차이를 넘어 실제 임상현장에서 언어재 활사 간 말더듬 평가의 신뢰도에 있어서도 매우 중요한 변수가 될 수 있기에 이러한 두 집단(즉, 일반인과 언어재활사) 간 비교 연구가 제공할 수 있는 임상적 함의 또한 결코 작다고 할 수 없다.

이에 본 연구에서는 특정음 연장의 지각에 있어서(언어장애 전문가인) 언어재활사 집단과 일반인 집단 사이의 지각 차이를 알아보고자 한다. 구체적으로, 한국어 1음절 어휘 '산'의 초성인 평마찰음 ''이 비정상적인 연장으로 인식되는 최소길이를 규명 하고자 한다. 아울러 이러한 연장음 지각의 양상(즉, 범주적으 로 인식되는지 아니면 연속적으로 지각되는지)을 알아보고, 두 집단 간의 차이를 알아보고자 한다. 이를 위해 본 연구에서는 평마찰음 'ㅅㅇㅢ 길이를 $20 \mathrm{~ms}$ 씩 연장해 생성된 문장자극 $(20 \mathrm{~ms}$ 의 정수배로 최종적으로 $380 \mathrm{~ms}$ 까지 연장해 변조한 19개)과 변조하지 않은 원래 문장 자극까지 총 20개의 음성샘플을 언어 재활사와 일반인들에게 들려주고 유창성 정도와 관련해 두 집 단 간 어떠한 지각 양상의 차이를 보이는지를 알아보고자 한 다. 이에 따른 연구 질문은 다음과 같다. 첫째, 한국어 평마찰 음 'ㅅ' 연장의 지각에 있어 언어재활사와 일반인 간에 비정상으 로 지각하는 연장음의 최소길이에 대한 수량적 기준에 차이가 있는가? 둘째, 한국어 평마찰음 ''의 연장음이 언어재활사와 일반인 집단 전체에서 범주적으로 지각되는가 또는 연속적으 
로 지각되는가? 셋째, 한국어 평마찰음 'ᄉ' 연장의 지각에 있어 언어재활사와 일반인 간에 비정상으로 지각하는 반응 정도(점 수)에 있어 유의미한 차이가 나타나는가?

\section{MATERIALS AND METHODS}

\section{연구 대상}

본 연구를 위한 실험은 한국어를 모국어로 하는 일반인 25 명 (남자 5명, 여자 20명, 평균연령 29.6, 표준편차 6.62)과 언어재활 사 25명(남자 2명, 여자 23명, 평균연령 30.3, 표준편차 7.73)을 대상으로 실시하였다. 집단 간 연령[t(48) $=-0.314, p=0.755]$ 과 성별 $\left[\chi^{2}(1)=1.495, p=0.221\right]$ 에 따른 유의한 차이는 나타나지 않았다. 실험대상자는 정상적인 시력과 청력을 가지고 있으며, 실험수행에 부정적 영향을 미칠 수도 있는 심리적, 정서적, 신 경학적 병력을 일체 가지고 있지 않으며, 과거에 음성 또는 언 어 문제로 평가나 치료를 받은 경험이 없고, 본인을 포함하여 친가 또는 외가 쪽으로 말더듬력이 없는 이로 선정하였다. 청력 검사는 순음청력검사를 실시하였으며 모두 정상역치(즉, 250 $\mathrm{Hz}$ 와 $4,000 \mathrm{~Hz}$ 구간에서 $25 \mathrm{~dB}$ 이하)의 청력을 보였다. 일반인 의 경우에는 특히 말더듬(인)에 대한 친숙 정도가 실험에 미치 는 영향을 최소화하기 위하여 말을 더듬는 사람을 만난 적이 없거나 있더라도 일정기간(즉, 1 개월 이상) 동안 정기적으로 만 난 경험이 없는 대상자로 선정하였다. 언어재활사의 경우에는, 현재 언어치료 관련 임상현장(예, 아동발달센터, 사설언어치료센 터, 장애인복지관)에서 근무하고 있는 2 급 이상의 자격을 소지 한 언어재활사로, 특히 아동 및 성인 유창성장애(말더듬) 임상 경력이 최소 6 개월 이상(평균경력 12.7 개월)인 이를 선정하였다.

\section{연구 절차}

모든 대상자는 실험 전에 실험에 대한 충분한 설명을 들은 후 서면동의서를 작성하였다. 본 실험에 앞서서 대상자에게 실 험 내용에 대해 간략한 설명을 제공하였다. 이후, 샘플평가(5개 문항)를 통해 대상자가 본 실험을 수행함에 용이하도록 하였다. 본 실험은 기본적으로 두 가지 세부 실험으로 구성되었다. 첫째, 각 문장자극을 듣고 정상(또는 유창함)과 비정상(또는 비유창 함)에 대한 이변량 척도( $(0$ 은 정상, 1 은 비정상)로 측정하였다. 둘 째, 각 문장자극을 듣고 비정상 정도에 대해 1부터 100점 척도 [100으로 갈수록 매우 비유창함(말더듬)]로 측정하였다. 본 실험 은 이변량 척도와 100점 척도 각각에 대해 20개의 음성샘플로 5 회씩 실시하였으며 각 회에서 (20개의) 문장자극은 무작위 순 서로 제공하였다. 결국, 실험당 총 100 회(20×5) 음성샘플을 듣 게 되는 것이다. 다음은 각 대상자에 제공한 실제 실험 설명의 예이다. "본 연구는 「특정 분절음 연장에 대한 지각 연구라는
주제로 분절음 연장의 인식 정도를 알아보고자 하는 것입니다. 검사에 소요되는 총 시간은 1 시간 이내입니다. 본 실험은 기본 적으로 문장을 듣고 특정 분절음이 얼마나 비정상적인지 그 정 도를 알아보는 실험입니다. 본 실험에 앞서 먼저 5 개의 샘플평 가가 주어집니다. 먼저 소리파일을 클릭하면 문장이 들립니다. 각 문장은 다양한 길이의 평마찰음을 포함하고 있습니다. 그 말소리가 정상적(유창함)인지 비정상적(비유창함)인지(0은 정 상, 1 은 비정상), 그리고 얼마나 비정상적으로 들리는지를 수치 [1-100, 100에 가까울수록 매우 비유창함(또는 말더듬)]로 적으 면 됩니다. 각 소리는 5 번까지 들을 수 있습니다. 끝까지 집중해 실험을 수행해 주시면 고맙겠습니다. 실험에 참여해 주셔서 감 사드립니다."

\section{자극음}

본 연구에서 사용되는 문장자극은 국내 언어치료 영역에서 가장 보편적으로 사용되고 있는 표준 문구 중 하나인 "가을 문 단”(Kim, 1996)의 두 문장인 “우리나라의 가을은 참으로 아름 답다. 산에 오를 땐 더욱더 그 빼어난 아름다움이 느껴진다.를 사용하였다. 연장 자극 생성을 위해 '산'의 초성인 평마찰음 '人' 의 길이를 변조(즉, 연장)하였다. 최대한 자연스러운 연장음을 만 들기 위하여, 기존의 음성편집기[예, Sound Forge (Sony Creative Software Inc., Middleton, WI, USA), Praat (Institute of Phonetic Sciences, University of Amsterdam, Amsterdam, the Netherlands)]를 통한 디지털 변조방식(Kawai et al., 2007)이 아닌 화자가 직접 발화한 샘플을 활용해 변조하였다. 구체적으 로, 먼저 ''을 1초(1000 ms)까지 연장발화한 후, 이 녹음 샘플 에서 평마찰음의 마찰구간(friction phase)이 안정적으로 발생 하는 시점을 기준으로 $20 \mathrm{~ms}$ 에서 시작해 $20 \mathrm{~ms}$ 간격으로 최 종적으로 $380 \mathrm{~ms}$ 까지(즉, $20 \mathrm{~ms}, 40 \mathrm{~ms}, 60 \mathrm{~ms}, \cdots, 340 \mathrm{~ms}$, $360 \mathrm{~ms}, 380 \mathrm{~ms}$ ) 총 19개의 샘플을 복사해 저장하고, 저장한 각각의 음성 샘플을 동일한 화자가 발화한 실험문장에서 ('산' 의) 평마찰음 ''의 마찰구간 정중앙에 삽입하였다. 생성된 결 과물에서 '산'의 평마찰음 지속시간 범위는 변조되지 않은 원래 마찰구간의 길이인 $205 \mathrm{~ms}$ 부터 최대 변조길이인 $585 \mathrm{~ms}$ 까지이 다. 변조 전 원래 평마찰음 'ᄉ'의 마찰구간(즉, $205 \mathrm{~ms}$ )은 정상 적 범위를 보였다(Lee, 2001).

특히, 둘째 문장의 첫 소리로 나타나는 '산의 평마찰음 ''을 연장자극으로 선택한 이유와 이와 관련된 몇몇 사항은 다음과 같다. 첫째, 말더듬은 주로 문장 시작 지점에 나타나며(Brown, 1945), 둘째, 유창한(즉, 연장이 없는) 문장(즉, '우리나라의 가 을은 참으로 아름답다.)을 먼저 들음으로써 이후의 비유창함 (또는 말더듬)의 인지를 더욱 용이하게 하기 위함이다. 셋째, 연 장은 마찰음이나 단모음과 같은 지속음(continuant)에서 주로 
나타난다(Lee, 2005). 나아가, 말속도가 유창성(정도)의 지각에 영향을 미칠 수 있기에(Starkweather, 1987), 이전 문장의 노출 을 통해 지각된 말속도를 바탕으로 비유창성(말더듬)에 대한 (상대적) 인지를 유도하기 위함이다(Kawai et al., 2007).

마지막으로, 문장자극 녹음에는 제2저자(남자, 35세)가 참여 하였다. 음성편집기인 Adobe Audition (version 3.0; Adobe Systems, San Jose, CA, USA)을 이용해 (변조된) 문장자극을 생성하였으며, 마이크(ECM-PC60; Sony, Tokyo, Japan)와 사 운드 블라스터(X-FI Surround 5.1 USB; Creative Technology, Singapore)를 이용하여 녹음하였다. Figure 1은 실험에 사용된 문장자극의 예이다.

\section{실험 장비 및 환경}

모든 실험은 방음처리가 되어 있는 대학 소재 음성학 실험실 에서 실시하였다. Figure 2에서 보이는 것처럼 컴퓨터(Samsung S24D300; Samsung Electronics, Suwon, Korea) 화면에 나오 는 엑셀(Microsoft Excel; Microsoft Corporation, Redmond, $\mathrm{WA}, \mathrm{USA}$ ) 파일에 포함된 각각의 문장을 듣고 0 (정상 또는 유창 함) 또는 1(비정상 또는 비유창함), 그리고 1에서 100점[100점으
로 갈수록 매우 비유창함(말더듬)] 척도로 응답하도록 하였다.

모든 문장자극은 이어폰(Microsoft LifeChat LX-3000; Microsoft Corporation)을 통해 적절한 세기(즉, $75 \mathrm{~dB} \mathrm{SPL}$ 이 내)(Rami et al., 2005)로 제공하였다. 해당 점수는 컴퓨터 자판 을 이용해 직접 입력할 수도 있고, 스크롤 막대를 움직여 입력 할 수도 있게 하였다. 총 응답은 0 1 척도와 1 100 척도 각각에 서 다섯 회로 이루어져 있으며 각 회에는 연장된 '슬 포함한 총 20개의 문장자극이 무작위로 배열되어 있다. 즉, 각 실험자 당 총 100 회 $(20 \times 5)$ 의 응답을 제공하도록 하였다.

\section{분석 절차}

비정상으로 지각하는 평마찰음 ''의 절단값(cut-off value)을 receiver operating characteristic (ROC) curve 분석과 Youden's index 검사를 통해 구하였다. 이를 통해 한국어 평마찰음 'ᄉ'의 연장 지각에 있어서 일반인과 언어재활사 간의 최소길이의 수 량적 기준에 차이가 나타나는지를 알아보았다. 또한 곡선추정 회귀분석을 통해 평마찰음 'ㅅ' 연장음의 길이와 비정상적으로 인식하는 영향관계를 분석하여 일반인과 언어재활사 간 지각 양상의 차이(즉, 범주적으로 지각되는지 아니면 연속적으로 지

Figure 1. Examples of sentence stimuli (A: the original, unaltered sentence stimulus, $B$ : the sentence stimulus prolonged by $380 \mathrm{~ms}$ with the altered portion highlighted using a dotted circle mark).

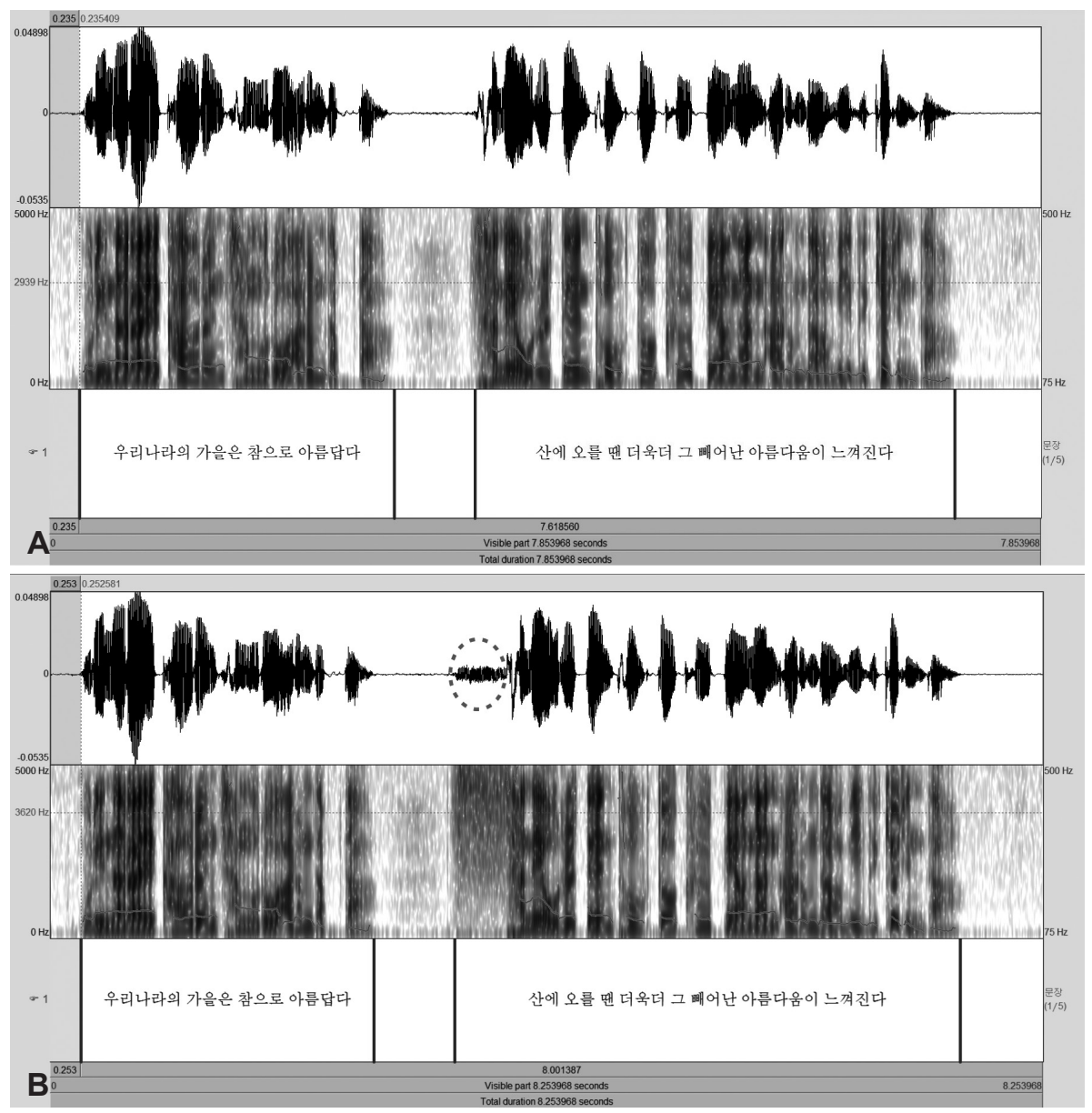




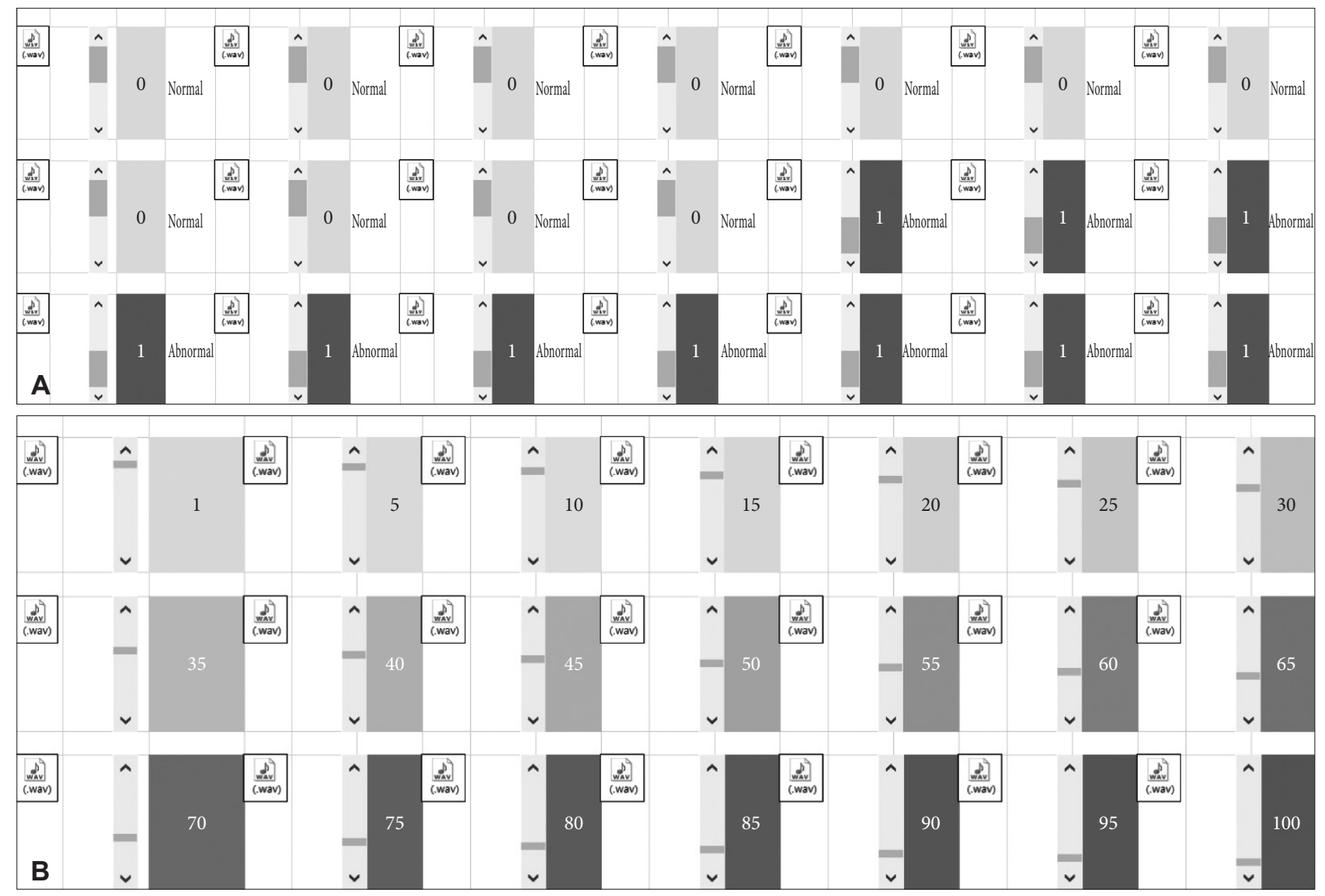

Figure 2. The rating scales used for determining and identifying sound prolongations (A: a rating of 0 or 1 , B: a rating of 1 to 100 ).
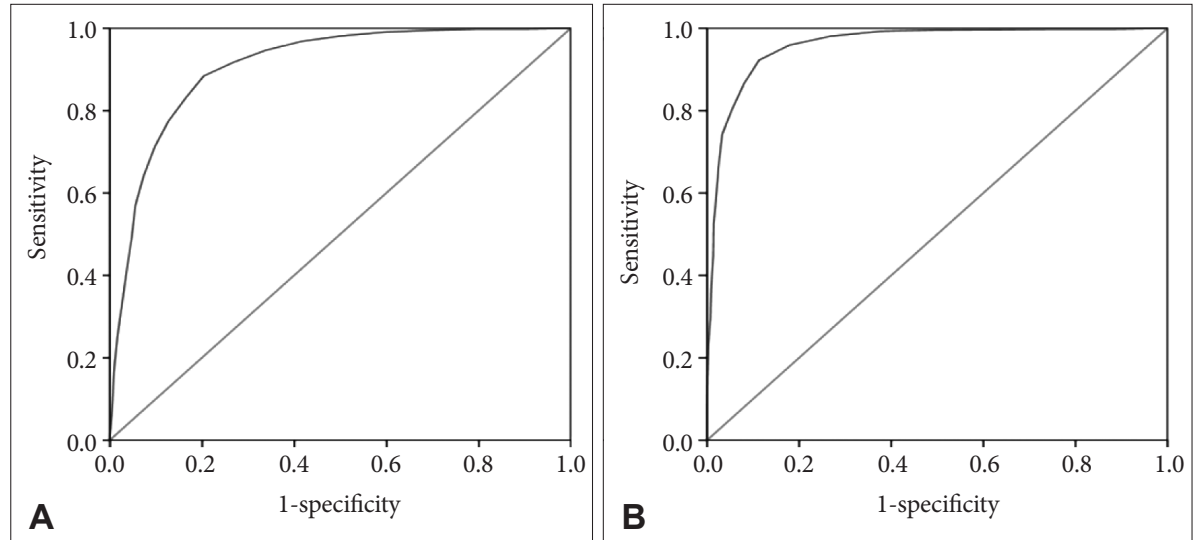

Figure 3. Receiver operating characteristic curve graphs [A: average adult listeners, B: speech-language pathologists, x-axis: 1-specificity (or non-specificity), y-axis: sensitivity].

각되는지)를 알아보았다. 마지막으로, 일반인과 언어재활사 간 의 비정상 인식 점수(1에서 100점까지)의 차이를 알아보기 위 해 이원분산분석(two-way ANOVA)을 실시하였다.

\section{RESULTS}

\section{비정상 지각의 최소길이}

ROC curve 분석과 Youden's index 검사결과, 일반인이 비유
창함으로 인지하는 'ㅅ' 연장음의 최소길이는 $375 \mathrm{~ms}$ 로 나타났 다[민감도 $=88.4 \%$, 특이도 $=79.6 \%$, area under ROC curve $(\mathrm{AUC})=0.908, p<0.001]$. 반면 동일한 연장음을 언어재활사 가 비유창함으로 인지하는 연장길이는 $355 \mathrm{~ms}$ 로 나타났다(민감 도 $=92.3 \%$, 특이도 $=88.7 \%, \mathrm{AUC}=0.961, p<0.001)$. 이 결과 치는 일반인보다 언어재활사가 'ㅅ 연장음을 비정상으로 인지하 는 최소길이가 상대적으로 더 짧음을 보이는 것이다. Figure 3 은 일반인과 언어재활사에 대한 ROC curve를 보여주고 있다. 


\section{0점 척도에 대한 곡선추정회귀분석}

100 점 척도로 평가한 모형에 대해 먼저 일반인은 3차 회귀모 형에 가장 적합한 것으로 나타났다 $\left(\mathrm{R}^{2}=0.378, p<0.001\right)$. 이 에 대한 회귀식은 $\mathrm{y}=-0.589 \mathrm{X}^{3}+0.002 \mathrm{X}^{2}-0.00000183$ 으로 나타났다. 언어재활사의 경우에도 일반인과 동일하게 3 차 회귀 모형에 가장 적합한 것으로 나타났으며 $\left(\mathrm{R}^{2}=0.618, p<0.001\right)$
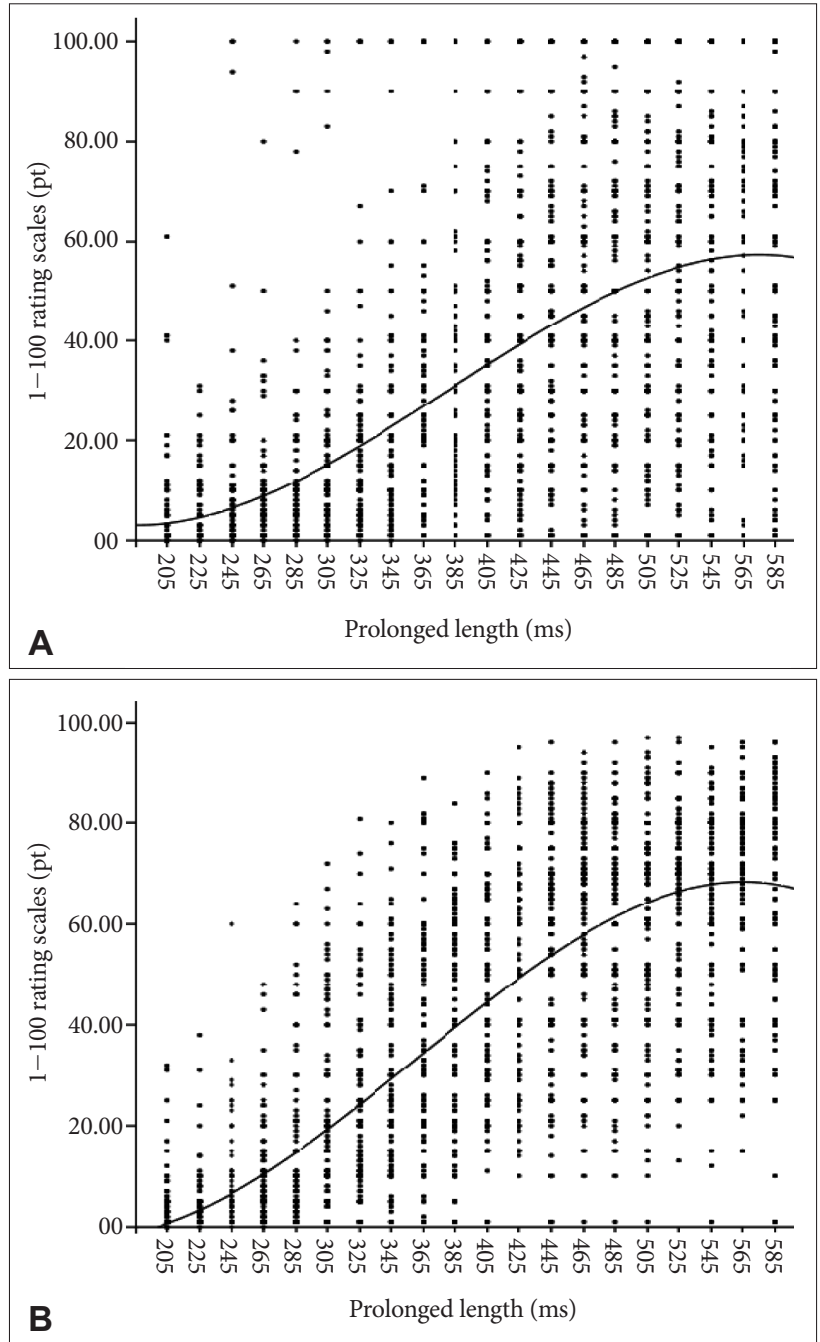

Figure 4. Curvilinear regression graphs (A: average adult listeners, $B$ : speech-language pathologists, $x$-axis: prolonged length, $y$-axis: $1-100$ rating scales).
회귀식은 $\mathrm{y}=-0.533 \mathrm{X}^{3}+0.002 \mathrm{X}^{2}-0.00000203$ 으로 나타났다. 이는 일반인과 언어재활사 모두 'ㅅ' 연장음을 단속적이라기보다 연속적으로 지각하고 있음을 보여주는 결과라고 할 수 있다. 또 한 일반인 $\left(\mathrm{R}^{2}=0.378\right)$ 보다 언어재활사 $\left(\mathrm{R}^{2}=0.618\right)$ 의 모형이 3 차 회귀모형에 상대적으로 더 적합해 설명력이 더 높은 것으로 나타났다. Figure 4와 Table 1은 곡선추정회귀 그래프와 통계결 과를 보여준다.

\section{0점 척도 반응의 집단과 연장길이 간 차이}

집단(즉, 일반인과 언어재활사)과 연장길이를 변수로 한 이원 분산분석 결과, 두 변수 간의 유의한 수준에서의 상호작용이 나타났다 $[\mathrm{F}(19,4,960)=2.913, p<0.001]$. 따라서 Kawai et al.(2007)의 분석방법을 따라 전체 연장길이 총 20개를 사분위 (quartile)로 나누어(즉, 제1사분위는 연장길이가 $205 \mathrm{~ms}$ 부터 $285 \mathrm{~ms}$ 까지, 제2사분위는 $305 \mathrm{~ms}$ 부터 $385 \mathrm{~ms}$ 까지, 제 3 사분위 는 $405 \mathrm{~ms}$ 부터 $485 \mathrm{~ms}$ 까지, 제4사분위는 $505 \mathrm{~ms}$ 부터 $585 \mathrm{~ms}$ 까지) 각 사분위에서의 집단과 연장길이에 대한 반응 점수 차 이를 알아보았다. 제 1 사분위에서 제 4 사분위로 갈수록 연장길 이가 점점 길어져 연장음이 더 비유창하게 들릴 수 있게 되는 것이다. 분석결과, 어떤 사분위에서도 집단과 연장길이 사이에 상호작용이 나타나지 않았다. 한편, 제 1 사분위에서는 집단 간 차이가 나타나지 않은 반면, 나머지 사분위에서는(즉, 제 $2,3,4$ 사분위) 모두 유의미한 집단 차이가 나타났다. 이는 (상대적으 로 연장길이가 짧아서 유창하게 들릴 수 있는 구간인) 제 1 사분 위에서는 일반인과 언어재활사 간 100점 척도를 바탕으로 한 점수에 있어 유의미한 차이가 없다가, 연장길이가 증가하면서 상대적으로 더 비유창하게 들릴수록 일반인보다 언어재활사가 유의미하게 높은 점수를 주고 있음을, 즉, 더 비유창하게 지각 함을 보여주는 결과이다. 각 사분위 내의 연장길이 반응(점수) 의 변화 중에서는 제 $1,2,3$ 사분위의 각 사분위 내에서는 유의 한 변화가 나타나지만 제 4 사분위 내에서는 유의한 변화가 나타 나지 않았다. 이는 연장길이가 가장 길어 매우 비유창하게 들리 는 제4사분위의 실험자극(505 ms부터 $585 \mathrm{~ms}$ 까지)에 대해서 는 공히 높은 반응(점수)으로 연장길이 간 차이가 유의하게 나 타나지 않음을 보여주는 결과이다. Table 2는 '서연장음 길이에

Table 1. Results of curvilinear regression analysis

\begin{tabular}{|c|c|c|c|c|c|c|}
\hline & Equations & $\mathrm{R}^{2}$ & $\mathrm{~F}$ & df1 & df2 & $p$-value \\
\hline \multirow[t]{3}{*}{ Average adult listeners } & Linear & 0.368 & $1,528.32$ & 1 & 2,623 & $<0.001$ \\
\hline & Quadratic & 0.371 & 774.62 & 2 & 2,622 & $<0.001$ \\
\hline & Cubic & 0.378 & 530.83 & 3 & 2,621 & $<0.001$ \\
\hline \multirow[t]{3}{*}{ Speech-language pathologists } & Linear & 0.595 & $3,846.96$ & 1 & 2,623 & $<0.001$ \\
\hline & Quadratic & 0.609 & $2,041.54$ & 2 & 2,622 & $<0.001$ \\
\hline & Cubic & 0.618 & $1,411.22$ & 3 & 2,621 & $<0.001$ \\
\hline
\end{tabular}


Table 2. Average ratings of the listeners at each duration point

\begin{tabular}{|c|c|c|c|c|}
\hline \multirow{2}{*}{$\begin{array}{c}\text { Duration } \\
\text { point } \\
(\mathrm{ms})\end{array}$} & \multicolumn{2}{|c|}{$\begin{array}{c}\text { Average adult } \\
\text { listeners }\end{array}$} & \multicolumn{2}{|c|}{$\begin{array}{c}\text { Speech-language } \\
\text { pathologists }\end{array}$} \\
\hline & Mean & SD & Mean & SD \\
\hline 205 & 4.32 & 8.84 & 3.48 & 5.30 \\
\hline 225 & 4.36 & 6.32 & 3.72 & 5.53 \\
\hline 245 & 7.74 & 16.23 & 5.71 & 8.34 \\
\hline 265 & 6.90 & 10.70 & 7.67 & 9.54 \\
\hline 285 & 11.16 & 16.55 & 11.99 & 14.71 \\
\hline 305 & 16.18 & 19.24 & 19.56 & 16.72 \\
\hline 325 & 16.97 & 19.56 & 22.89 & 17.53 \\
\hline 345 & 20.66 & 21.43 & 26.74 & 18.45 \\
\hline 365 & 26.14 & 21.80 & 35.79 & 21.52 \\
\hline 385 & 32.44 & 24.68 & 42.48 & 22.45 \\
\hline 405 & 38.19 & 26.92 & 46.78 & 21.84 \\
\hline 425 & 38.34 & 26.76 & 52.57 & 21.21 \\
\hline 445 & 45.70 & 27.98 & 55.49 & 22.39 \\
\hline 465 & 48.45 & 28.47 & 60.61 & 20.56 \\
\hline 485 & 51.42 & 29.76 & 59.29 & 21.14 \\
\hline 505 & 50.57 & 29.90 & 59.75 & 21.78 \\
\hline 525 & 54.32 & 32.11 & 65.41 & 19.09 \\
\hline 545 & 52.87 & 30.52 & 65.61 & 20.12 \\
\hline 565 & 55.26 & 32.51 & 68.06 & 20.60 \\
\hline 585 & 55.59 & 30.82 & 66.43 & 22.43 \\
\hline
\end{tabular}

SD: standard deviation

대한 일반인과 언어재활사의 100점 척도에서의 평균점수를, Table 3은 각 사분위에서의 집단과 연장길이에 관한 통계결과 를 보여준다.

\section{DISCUSSIONS}

본 연구의 결과를 요약해 보면, 첫째, 한국어 평마찰음 'ㅅㅇㅢ 연장음에 있어 비정상으로 지각하는 최소길이에 있어 언어재 활사 집단과 일반인 집단 사이에 차이가 나타났다. 구체적으로, 언어재활사가 비유창함으로 지각하는 연장음 길이는 $355 \mathrm{~ms}$ 인 반면, 일반인은 $375 \mathrm{~ms}$ 로 나타났다. 언어재활사가 일반인보다 '' 연장음을 비정상으로 지각하는 최소길이가 상대적으로 더 짧음을 보여주고 있다. 둘째, 언어재활사와 일반인 모두 연장길 이가 증가할수록 비정상적인 말소리로 인식하였으며, 완만한 $\mathrm{S}$ 곡선 모양(sigmoidal curve)의 연속선 형태로 나타났다. 이는 (두 집단 모두) '' 연장음을 단속적이라기보다 연속적으로 지 각하고 있음을 시사하는 것이다. 셋째, 100점 척도를 바탕으로 한 평가 반응점수에 있어 상대적으로 연장길이가 짧아 유창하 게 들릴 수 있는 구간(즉, $205 \mathrm{~ms}$ 부터 $285 \mathrm{~ms}$ 까지의 제 1 사분 위)에서는 유의한 차이가 없다가 연장길이가 증가하면서 더 비 유창하게 들리는 구간(즉, $305 \mathrm{~ms}$ 부터 $585 \mathrm{~ms}$ 까지 제 2,3 , 4사
Table 3. Results of two-way ANOVA for each of the 4 quartiles

\begin{tabular}{|c|c|c|c|c|c|}
\hline & $\begin{array}{l}\text { Type III } \\
\text { sum of } \\
\text { squares }\end{array}$ & df & $\begin{array}{l}\text { Mean } \\
\text { square }\end{array}$ & $\mathrm{F}$ & $\begin{array}{c}p- \\
\text { value }\end{array}$ \\
\hline \multicolumn{6}{|l|}{ 1st quartile } \\
\hline Group & 66.817 & 1 & 66.82 & 0.38 & 0.54 \\
\hline Duration point & $29,180.43$ & 4 & $7,295.11$ & 41.72 & 0.00 \\
\hline Group $\times$ duration point & $1,012.69$ & 4 & 253.17 & 1.45 & 0.22 \\
\hline \multicolumn{6}{|l|}{ 2nd quartile } \\
\hline Group & $20,289.04$ & 1 & $20,289.04$ & 42.78 & 0.00 \\
\hline Duration point & $87,362.82$ & 4 & $21,840.71$ & 46.05 & 0.00 \\
\hline Group $\times$ duration point & 950.66 & 4 & 237.67 & 0.50 & 0.74 \\
\hline \multicolumn{6}{|l|}{ 3rd quartile } \\
\hline Group & $35,409.93$ & 1 & $35,409.93$ & 55.47 & 0.00 \\
\hline Duration point & $18,042.24$ & 4 & $4,510.56$ & 7.07 & 0.00 \\
\hline Group $\times$ duration point & $1,604.37$ & 4 & 401.09 & 0.63 & 0.64 \\
\hline \multicolumn{6}{|l|}{ 4th quartile } \\
\hline Group & $41,610.36$ & 1 & $41,610.36$ & 58.63 & 0.00 \\
\hline Duration point & $5,306.76$ & 4 & $1,326.69$ & 1.87 & 0.11 \\
\hline Group $\times$ duration point & 338.95 & 4 & 84.74 & 0.12 & 0.98 \\
\hline
\end{tabular}

df: degree of freedom

분위)에서는 언어재활사가 일반인보다 유의미하게 높은 점수 를 주었다. 즉, 일반인보다 언어재활사가 더 비유창하게 지각하 고 있음을 보여주는 것이다.

이러한 결과를 바탕으로 몇 가지 논의를 해보자면, 첫째, 평 마찰음 'ㅅㅇㅢ 연장음 인식에 있어서 언어재활사가 일반인보다 비정상으로 인지하는 최소길이가 더 짧다는 것은 청자에 따라 비정상 또는 비유창함으로 인지하는 최소길이의 차이가 발생 할 수 있다는 것을 보여주는 것이라고 할 수 있다. 서론에서 언 급한 것처럼 언어재활사는 유창성장애(말더듬) 평가 및 치료의 전문가 집단으로서 말더듬(인)에 대한 경험이 없거나 상대적으 로 적은 일반인에 비해 높은 말더듬 지각(또는 파악) 능력을 가 지고 있다고 할 수 있다. 이러한 언어재활사의 지각 양상은 연 장음의 비정상 정도를 파악함에 있어서 더욱 민감하며 일반인 이 정상적으로 지각한 연장음 $($ 즉, $355 \mathrm{~ms})$ 을 비정상적으로 지 각한 것이라고 하겠다. 또한 비정상 정도와 관련해 1 100점 척 도를 바탕으로 한 점수에 있어서도 연장음이 길어 상대적으로 비유창하게 들릴수록 일반인에 비해 언어재활사가 유의미하게 높은 점수를 주고 있었다. 즉, 연장길이가 상대적으로 긴 연장 음에 대해 언어재활사가 더 비유창하게 지각하고 있다는 것이 다. 이는 비유창함에 대한 지각에 있어서 더욱 민감한 언어재 활사의 특성을 잘 보여주고 있는 결과라고 할 수 있겠다.

둘째, 언어재활사와 일반인 모두 '' 연장음을 단속적이라기 보다 연속적으로 지각하고 있음은 이전 영어권 화자를 대상으 로 마찰음 $/ \int /$ 를 연장하여 지각실험을 실시하였던 Kawai et 
$\mathrm{al}$.(2007)과 거의 동일한 결과이다. Figure 4에 나타난 것처럼, 두 집단 모두 연장길이가 증가할수록 비정상으로 지각하였으며 점진적으로 증가하는 양상을 보였다. Voice onset time (VOT) 과 같은 범주적 지각(Eimas et al., 1971)에서 전형적으로 나타 나는 것과 달리, 상대적으로 연장길이가 짧아 더 유창하게 들 리는 구간(예, $205 \mathrm{~ms}$ 부터 $285 \mathrm{~ms}$ 까지의 제 1 사분위)이나 연장 길이가 길어 더 비유창하게 들리는 구간(예, $505 \mathrm{~ms}$ 부터 585 $\mathrm{ms}$ 까지의 제 4 사분위)에서 비정상 지각 정도(점수)에 변화가 거 의 없는 완만한 평행선 형태로 나타나는 '바닥현상'이나 '천정 현상'이 나타나지 않았다. 아울러 중간 구간에서 비정상으로 지 각하는 정도가 갑작스럽게(exponentially) 증가하는 현상도 나 타나지 않았다. 이는 모두 'ㅅ' 연장을 단속적이라기보다는 연속 적으로 지각하고 있음을 보여주는 결과라고 할 수 있다. 하지 만 각 사분위 내에서 연장길이에 따른 반응(점수)의 변화에 있 어서 (제1, 2, 3사분위와는 다르게) 제4사분위에서 유의한 변화 가 나타나지 않았다는 결과(Table 3)는 일종의 '천정효과'로 해 석될 수 있는 여지가 있기에 완전한 형태의 연속선으로 해석하 기에는 주의가 요구된다고 하겠다.

셋째, 점진적인 VOT 연장을 단속적으로 인지한 영유아에 대 한 Eimas et al.(1971)의 보고와 달리, 본 연구에서 보이는 'ᄉ' 연장음의 연속적 지각에 대해 생각해 봄직한 이유를 간단히 언급한다. 그중 처음으로는 응답 대상 소리의 지위에 대한 사항 이다. VOT 연장음 지각실험에서는 지각의 대상인 두 소리가 모두 해당 언어의 음소이다. 이에 반해, 본 연구에서는 판정하 여 답으로 선택할 사항이 하나는 해당 언어의 적법한 음소인 반 면 다른 선택사항은 해당 언어에 나타나지 않는 비정상적인 소 리이다. 이러한 차이가 응답자로 하여금 다른 양상의 응답을 산 출하게 했을 가능성이 있다. 둘째로는, 실험의 설계이다. VOT 연장음 지각 연구에서는 VOT 연장음을 들려주고, 이를 들은 응답자가 반응한 것을 관찰하는 것인 반면, 본 연구에서는 응 답자가 들은 소리를 적극적으로 숙고하고 자신이 지각한 소리 라고 생각되는 답을 선택하였다. 이러한 설계의 차이가 다른 결 과를 내놓을 가능성도 있을 것이다. 다른 차이는 응답자에 대 한 것이다. VOT 실험의 대상자는 생후 1 개월에서 4 개월까지의 영유아인 반면, 본 연구의 실험참여자는 20 40대의 성인이다. 이러한 차이 또한 무시할 수 없을 것이다. 이러한 차이가 응답 의 양상에 차이를 유발하는지에 대한 고찰도 필요하겠다.

넷째, 본 연구에서는 연장음의 길이에 따라 (비)유창함 정도 를 두 가지 실험상황에서 평가하였다. 하나는 연장음을 이변량 척도(0 또는 1), 다른 하나는 다변량 척도(1에서 100 까지)를 바 탕으로 평가한 것이다. 하나의 실험상황은 다양한 길이로 제공 되는 연장음에 대해 단 두 가지 척도로만 평가하게 한 것이고, 다른 하나는 상대적으로 폭넓은 응답 범위를 제공하고 이를 바
탕으로 비유창성 정도를 더 세밀하게 평가하게 한 것이다. 유창 성이 단지 정상/비정상 또는 유창함/비유창함으로 구분되는 단속적으로 지각되는 개념이 아닌 유창함에서 매우 비유창함 (또는 말더듬)에 이르는 연속적인 지각 개념이라면(Adams \& Runyan, 1981), 이를 단 두 개의 척도로만 평가하는 것은 실제 로 나타나는 지각 양상을 제대로 반영하지 못할 가능성이 있 다. Kawai et al.(2007)에서는 만약 유창성이 단속적으로 지각 되는 개념이라면 이변량 척도뿐 아니라 100점 척도에서도 단속 적인(즉, 바닥현상, 천정현상, 그리고 중간에 급증하는 현상이 나타나는) 양상이 나타날 것이라는 가정에서 출발한다. 그러나 이러한 가정과는 다르게 100점 척도를 바탕으로 했을 때 단속 적이라기보다 연속적인 지각 양상을 보였다. 결국 유창성 정도 는 단지 정상/비정상 또는 유창함/비유창함으로 단속적 양상 이 아닌 실제로는 유창함에서 비유창함(또는 말더듬)으로 이르 는 연속적인 지각 양상을 보인다고 말할 수 있는 것이다.

마지막으로 본 연구결과와 관련한 임상적 함의를 기술하자 면, 무엇보다도 말소리 연장에 대한 연속적 개념에 입각한 평가 체계가 수립되어야 할 것이다. 0.5 초 이상이면 말소리 연장으로 규정하는 방식(Van Riper, 1982)보다는 연속적 지각 개념에 입 각한 척도를 개발, 이를 활용한 평가 방식(Schiavetti et al., 1983; Schiavetti et al., 1994)을 시도해 볼 것을 제안한다. Gregory(2003)의 주장처럼 말더듬으로 인식되는 연장은 분절음 간 의 차이, 음조나 긴장과 관련된 질적 변화의 유무, 말속도, 청자 의 차이에 따라 상이한 결과를 보일 수 있다. 본 연구에서도 말 더듬(인)에 대한 경험 또는 전문성 여부(즉, 언어재활사와 일반 인 간)에 따라 연장으로 인식하는 최소길이에 차이가 나타났 다. 이러한 맥락에서 더욱 특정 수치(예, 0.5초 이상)에 따른 연 장 평가 방식을 고수하기보다 하나의 연속선상에서 넓은 (수 치) 구간을 바탕으로 한 수량적 평가 기준(Kawai et al., 2007; Kawai \& Healey, 2012)을 제시해 이를 실제 임상에서 사용해 볼 것을 제안해 본다.

본 연구의 제한점과 이에 관련해 제안해 볼 수 있는 (가능한) 후속연구는 다음과 같다. 첫째, 본 연구는 연장음 인식 양상 (즉, 단속적으로 또는 연속적으로 지각하는지)에 대해 기본적 으로 Kawai et al.(2007)의 실험 방식을 바탕으로 수행되었다. 따라서 Kawai et al.(2007)이 언급한 제한점이 본 연구에서도 동일하게 적용된다고 할 수 있다. 구체적으로, 본 연구에서는 문장 내 특정음(즉, 'ㅅ')만을 (변조) 연장하였다. 따라서 다른 분 절음(예, 모음이나 유음)을 변조해 비정상적으로 지각하는 최 소길이나 관련한 지각 양상(즉, 단속적으로 또는 연속적으로 지각하는지)에 대한 연구도 수행할 필요가 있겠다. 둘째, 본 연 구에서는 다변량 척도를 1 부터 100 까지로 하여 지각 정도를 평 가하고 있는데, 이는 차별적으로 지각하여 응답하기에 어려울 
정도로 미세하고 너무 많은 것일 수 있다. 이 수를 줄여서, 예를 들어, 1 부터 10 까지의 척도로 한다면 차별적(혹은 변별적)으로 응답하기에 횔씬 용이할 수 있겠고 나아가 실험참여자의 응답에 대한 신뢰도가 높아질 수도 있을 것이다. 셋째, Gregory(2003)의 주장처럼 연장음 인식에 다른 여러 변수(예, 말속도, 말더듬 중 증도, 부수행동의 유무, 청자 등)가 영향을 미칠 수 있기에 향후 연장길이뿐 아니라 이러한 다른 여러 변수들이 연장 지각에 어 떤 영향을 미치는지에 대한 연구도 실시할 필요가 있겠다. 예를 들어, 동일한 연장음에 대해 말속도(즉, 초당발화음절수)의 차 이에 따라 비유창성 지각에 어떤 변화가 발생하는지를 알아볼 필요가 있다고 하겠다. 또한 청자가 아닌 화자에 따른(예, 말더 듬 아동과 성인, 말더듬 성인 남성과 여성) 연장 인식의 차이가 발생하는지도 알아볼 필요가 있겠다. 넷째, 연구방법에서 언급 한 것처럼 본 연구에서는 최대한 자연스러운 연장음을 생성하 기 위해 기존의 음성 편집기를 이용한 디지털 변조방식(Kawai et al., 2007)이 아닌 화자가 직접 발화한 샘플을 활용해 변조한 문장자극을 생성하였다. 따라서 기존의 디지털 변조 방식과 화 자가 직접 발화한 샘플을 활용해 변조하는 방식 사이에 변조로 인한 음질의 문제와 관련된 자연성 정도에 있어 차이가 나타나 는지에 대한 연구도 필요하다 하겠다. 다섯째, 더 넓은 구간(예, $205 \mathrm{~ms}$ 부터 1,000 ms까지)을 아우르는 연장 변조를 통해 실험 을 수행할 필요도 있겠다. Kawai et al.(2007)이 지적한 것처럼, 이를 통해 본 실험에서는 나타나지 않았던 범주적 지각의 특징 적 양상 즉, ‘바닥현상' 또는 '천정현상' 등이 관찰될 가능성도 있기 때문이다. 마지막으로, 다양한 대상, 예를 들어, 음성인식 (처리) 전문가나 말더듬인 가족 등과 같은 집단과 일반인 집단 을 비교한 연구를 진행해 본 연구를 통해 나타난 언어재활사와 일반인의 차이가 이러한 집단 사이에도 동일하게 나타나는지 를 알아볼 필요가 있겠다. 또한 언어재활사의 유창성장애(말더 듬) 관련 임상경력(기간)에 따른 연장의 인식 차이에 대한 연구 도 필요할 것으로 사료된다. 요컨대, 위에서 언급한 다양한 사 항을 고려하여 향후에 말더듬으로서 연장 인식에 대한 더욱 다 양하고 세밀한 연구가 수행되기를 기대해 본다.

중심 단어 : 말더듬-말소리 연장 - 단속적 지각-연속적 지각한국어 평마찰음 'ㅅ'

\section{Ethical Statement}

The entire procedure of this research was approved by the Institutional Review Board of Catholic Kwandong University (IRB no. CKU-18-020102).

\section{Acknowledgments}

The authors are grateful to the participants of this study and Minji Kang, who is a graduate student in the Department of English, Sogang University.

\section{Declaration of Conflicting Interests}

There are no conflict interests.

\section{Funding}

This work was supported in part by the Research Fund of Catholic Kwandong University (no. 201705150001) and the 2017 Sogang University Research Grant (no. 201710126.05).

\section{REFERENCES}

Adams, M. R. \& Runyan, C. M. (1981). Stuttering and fluency: Exclusive events or points on a continuum? Journal of Fluency Disorders, 6(3), 197-218.

Brown, S. F. (1945). The loci of stuttering in the speech sequence. Journal of Speech and Hearing Disorders, 10, 181-192.

Eimas, P. D., Siqueland, E. R., Jusczyk, P., \& Vigorito, J. (1971). Speech perception in infants. Science, 171(3968), 303-306.

Gregory, H. H., Campbell, J. H., Gregory, C. B., \& Hill, D. G. (2003). Stuttering Therapy: Rationale and Procedures. Boston, MA: Allyn and Bacon.

Jones, K., Logan, K. J., \& Shrivastav, R. (2005). Poster presented at the annual meeting of the American Speech-Language-Hearing Association: Duration, Rate, and Phoneme-Type Effects on Listeners' Judgments of Prolongations. San Diego, CA: San Diego Convention Center.

Kawai, N. \& Healey, E. C. (2012). Poster presented at the annual meeting of the American Speech-Language-Hearing Association: Listeners' Perception of Digitally Manipulated Moments of Audible Hesitations. Atlanta, GA: Georgia World Congress Center.

Kawai, N., Healey, E. C., \& Carrell, T. D. (2007). Listeners' identification and discrimination of digitally manipulated sounds as prolongations. The Journal of the Acoustical Society of America, 122(2), 1102-1110.

Kim, H. H. (1996). Perceptual, acoustical, and physiological tools in ataxic dysarthria management: A case report. Proceedings of the second conference of the Korean Society of Phonetic Sciences and Speech Technology (pp. 9-22). Seoul National University, Seoul.

Lee, K. H. (2001). A study of Korean fricatives. (Unpublished doctoral dissertation). Korea University, Seoul.

Lee, S. W. (2005). Fluency Disorders. Seoul: Sigmapress.

Liberman, A. M., Delattre, P. C., \& Cooper, F. S. (1958). Some cues for the distinction between voiced and voiceless stops in initial position. Language and Speech, 1(3), 153-167.

Lingwall, J. B. \& Bergstrand, G. G. (1979). Poster presented at the annual meeting of the American Speech-Language-Hearing Association: Perceptual Boundaries for Judgments of "Normal," "Abnormal," and "Stuttered" Prolongations. Atlanta, GA: Georgia World Congress Center.

Lisker, L. \& Abramson, A. S. (1967). Some effects of context on voice onset time in English stops. Language and Speech, 10(1), 1-28.

Perkins, W. H. (1983). The problem of definition: Commentary on "stuttering." Journal of Speech and Hearing Disorders, 48(3), 246-249.

Pisoni, D. B., Lively, S. E., \& Logan, J. S. (1994). Perceptual learning of nonnative speech contrasts: Implications for theories of speech perception. In Goodman, J. C. \& Nusbaum, H. C. The Development of Speech Perception: The Transition from Speech Sounds to Spoken Words (pp. 121-166). Cambridge, MA: The MIT Press.

Rami, M. K., Kalinowski, J., Rastatter, M. P., Holbert, D., \& Allen, M. (2005). Choral reading with filtered speech: Effect on stuttering. Perceptual and Motor Skills, 100(2), 421-431.

Schiavetti, N., Martin, R. R., Haroldson, S. K., \& Metz, D. E. (1994). Psychophysical analysis of audiovisual judgments of speech naturalness of nonstutterers and stutterers. Journal of Speech and Hearing Research, $37(1), 46-52$.

Schiavetti, N., Sacco, P. R., Metz, D. E., \& Sitler, R. W. (1983). Direct magnitude estimation and interval scaling of stuttering severity. Journal of Speech and Hearing Research, 26(4), 568-573.

Shin, M. \& Choi, S. Y. (2012). A grounded theory analysis on the experience 
of speech pathologist with stuttering therapy. Communication Sciences and Disorders, 17(2), 201-218.

Sommers, R. K. \& Caruso, A. J. (1995). Inservice training in speech-language pathology: Are we meeting the needs for fluency training? American Journal of Speech-Language Pathology, 4(3), 22-28.

Starkweather, C. W. (1987). Fluency and Stuttering. Englewood Cliffs, NJ: Prentice-Hall.

Susca, M. \& Healey, E. C. (2002). Listener perceptions along a fluency--disfluency continuum: A phenomenological analysis. Journal of Fluency Disorders, 27(2), 135-161.
Susca, M., Healey, E. C., Petsche, D., Potter, A., \& McCreery, R. (2001). Poster presented at the annual meeting of the American Speech-Language-Hearing Association: Effects of Age and Gender on Perceptions of Stuttering and Fluency. New Orleans, LA: New Orleans Convention Center.

Van Riper, C. (1982). The Nature of Stuttering (2nd ed.). Englewood Cliffs, NJ: Prentice-Hall.

Wingate, M. E. (1988). The Structure of Stuttering: A Psycholinguistic Analysis. New York, NY: Springer-Verlag. 